\author{
Peter Šturák ${ }^{1}$ \\ Prešovská univerzita v Prešove \\ Gréckokatolícka teologická fakulta
}

\title{
The situation of the Greek Catholic Church in Slovakia in the second half of $20^{\text {th }}$ century
}

The Greek Catholic Church in Slovakia has been through many trials throughout its history but it suffered most notably in the second half of $20^{\text {th }}$ century. It still persevered, however, in its faith and devotion to God and the Holy Father. Whereas the other Churches were being crumbled and weakened, the Greek Catholic Church in Slovakia (or rather in the former Czechoslovakia) was being downright eliminated and outlawed by

1 In 1998, I graduated in Theology from the Faculty of Theology of Cyril and Methodius in Bratislava. In the same year I took holy orders and was ordained a priest in the Cathedral of St. John the Baptist in Prešov. In 1997, I obtained a Licentiate in Theology from the Papieska Akademia Teologiczna in Krakow. Two years later I was awarded a Doctoral degree in Theology and also an academic degree PhD. In 2003 I received a degree of Associate Professor from the Catholic University in Ružomberok and there I was also inaugurated Professor of Theology. In 1996, I started lecturing at the Greek-Catholic Theological Faculty of Prešov University in Prešov. In my scientific, academic and publication work I specialise in historical sciences. In addition to Christian medieval history, the focus of my research is primarily on history of the Greek-Catholic Church in the $20^{\text {th }}$ century. I am a member of various scientific and editorial boards, both in Slovakia and abroad. I am an author or a co-author of several monographs and numerous scientific studies. In addition to my educational work, I have held some academic posts such as Vice-Rector for international relations and currently I serve as Dean of the Greek-Catholic Theological Faculty of Prešov University in Prešov. E-mail: peter.sturak@unipo.sk. 
the administration. It suffered most notably from the pressure of totalitarian power and even produced its martyrs.

This fact was emphasized by the Pope, at the time Saint John Paul II on the $2^{\text {nd }}$ June 1995 upon meeting the Greek Catholic believers in Prešov, when he included in his address: "We all remember the dramatic situation of the recent past, when the forces of ideology which is at variance with human freedom and dignity, sentenced your church community to extermination. Greek Catholic Community emerged from this trial renewed and strengthened due in no small part to the testimony and blood of numerous martyrs. The faith of a great number of laymen, monks, nuns, priests and pastors is its living legacy. Suffice is to mention the suffering of the Bishop Vasil Hopko and the martyrdom of the Bishop Pavol Gojdič." ${ }^{2}$

I will start the first part of my study by introducing the situation in which the Greek Catholic Church found itself in the former Czechoslovakia after the events of so called "Sobor (council) of Prešov" in April 1950 when it was downright liquidated by totalitarian regime and how its pastors reacted to this situation, namely the residential Bishop Peter Gojdič O.S.B.M. and his Auxiliary Bishop ThDr. Vasil' Hopko, but also the priests and the believers. In the second part I will focus in detail on the events of 1968, when under the influence of society-wide changes in Czechoslovakia there was a reform process and one of its aspects also included the permission for the Greek Catholic Church to function. The next part will focus on the period of 1969-1989, when under the influence of "normalization" of affairs the Greek Catholic Church found itself in a situation, where its functioning was permitted but its presence barely tolerated. The last part will describe all the positive facts in its life that took place in the times of freedom due to the democratization changes in our society after 1989 up until today.

2 G. Székely, A. Mesaroš, Gréckokatolíci na Slovensku, Košice 1997, p. 83. 


\section{The situation of the Greek Catholic Church in the former Czechoslovakia after the events of the so called "Sobor of Prešov” in 1950}

The end of World War II brought a new division of the world. Czechoslovakia was under the ideological influence and power of Moscow. The fall of the democratic systems and their replacement by totalitarian ones affected all eastern European states including our homeland. The accession of communistic power intervened radically with all areas of life and on the ideological level the most ferocious war was waged against the Church, earning the epitome of its "most militant form" in Czechoslovakia.

The plan for the liquidation of the Church had its designated strategy, its stages and tactics laid out in individual steps. After the ultimate usurpation of power following the so called February Events in 1948, a preparation phase was launched for the harshest liquidation interventions in 1950, including the liquidation of monasteries and convents, internment and conviction of bishops and the liquidation of the Greek Catholic Church which was the first to bear the brunt. The liquidation of the Greek Catholic Church in Czechoslovakia on $28^{\text {th }}$ April 1950 by the so called "Sobor (council) of Prešov" on the institutional level hardly meant its destruction as such, considering the fact that the Church is a divine/ human institution and so is, in its divine essence, indestructible. It went on living, in the form of its suffering limbs in prisons, such as the two bishops (Bishop Pavol Peter Gojdič O.S.B.M. and Bishop ThDr. Vasil' Hopko), many priests and lay believers in exile on the Czech frontier. ${ }^{3}$

Bishop Pavol Peter Gojdič O.S.B.M. suffered an especially trying fate and the martyr's death $(1888-1960)^{4}$ as the highest pastor of his Church,

3 See: J. Coranič, TZV. „Prešovský sobor” - vyvrcholenie úsilia totalitnej moci o likvidáciu Gréckokatolíckej cirkvi v Československu, [in:] Cirkev v okovách totalitného režimu. Likvidácia Gréckokatolíckej cirkvi v Československu v roku 1950, eds. J. Coranič, P. Šturák, J. Koprivňáková, Prešov 2010, p. 63.

4 Pavol Peter Gojdič was born on $17^{\text {th }}$ July 1888 in the village Ruské Peklany into the family of the Greek Catholic priest. After completing his primary and secondary education, he then sudied theology in Prešov and Budapest. He was ordained a priest on $27^{\text {th }}$ August 1911 in Prešov. He held numerous posts within the Episcopal Curia, starting with a post of administration clerk and ending with a post of a director of the Episcopal Office. On $20^{\text {th }} \mathrm{July} 1922$ 
right in the time when the totalitarian power was attempting to destroy the Greek Catholic Church in the former Czechoslovakia. After the infamous circumstances of "Sobor of Prešov" held on $28^{\text {th }}$ April 1950, Father Bishop Gojdič set out on his path of thorns. On $20^{\text {th }}$ September 1950 after a short internment he was transported to one of the toughest prisons at Ruzyne in Prague, where he was subjected to inhuman treatment during the pre-trial custody right up until the date of his trial in January 1951 in Bratislava. It was followed by his imprisonment in the northeast Czech Republic by Jičín in Valdice that lasted until 10 ${ }^{\text {th }}$ December 1951 when he was transported to the prison in Leopoldov, then to Ilava and then back to Leopoldov where he also died on the day of his seventieth birthday as a martyr of faith and devotion to God and Church. ${ }^{5}$ Great people need not be praised; their actions speak for themselves. These words fully characterize the life and death of the great Bishop Pavol Peter Gojdič O.S.B.M. The example of his life became a source of strength for many. He became the well of peace for those who suffered for their faith in the past years: for priests, monks, believers and all those who loved their Cyril and Methodius Byzantine Rite and did not renounce their love and devotion.

Like Bishop Gojdic, the Auxiliary Bishop of Prešov ThDr. Vasil' Hopko (1904-1976) ${ }^{6}$ was also a thorn in the side of the totalitarian power. After

he entered the Order of St Basil in Černečia Hora near Mukačevo. On $14^{\text {th }}$ September 1926 he was ordained a Apostolic Administrator of Prešov Eparchy. In the same year, on $28^{\text {th }}$ November he took his eternal vows in the Order of St Basil the Great. On $25^{\text {th }}$ March 1927 he was consecrated a Bishop in the St Clement Basilica in Rome. As a bishop he zealously served his office, he contributed to the spiritual elevation of clergy and believers, his work was significant in the social area and ecclesiastical education. On $17^{\text {th }}$ July 1940 he was appointed a Residential Bishop in Prešov. In 1950, after the infamous events of so called "Sobor (council) of Prešov", Pavol Peter Gojdič was interned and then kept in prisons in Czechoslovakia. On $15^{\text {th }}$ Janury he was sentenced to life in prison by the State Court in Bratislava. He was also deprived of his civil rights and he had his property confiscated. He died as martyr in fidelity to the Church and the Holy Father on $17^{\text {th }}$ July 1960 in the prison in Leopoldov. On $4^{\text {th }}$ November 2001 he was beatified by Holy Father John Paul II in Rome.

5 M. Hromník, Blahoslavený Pavel Peter Gojdič, OSMB, Prešov n. o. 2007, p. 23-26.

6 Vasil' Hopko was born on $21^{\text {st }}$ April 1904 in the village of Hrabské, near Bardejov. He received his primary and secondary education in Bardejov and Prešov. He graduated from the Hungarian Evanjelical Grammar School in Prešov. He completed his theological stud- 
the framing trial on $24^{\text {th }}$ October 1951 by the State Court in Bratislava, he was sentenced to fifteen years of prison. ${ }^{7}$ The location of his imprisonment included the prisons in Czech Republic, namely Ruzyne, Mírov and Valdice. ${ }^{8}$ After many years of imprisonment and torture, on $12^{\text {th }}$ May 1964 the authorities broke off his sentence in consideration of his extremely serious condition and fearing he would die in prison. His new place of residence was the former Cistercian Abbey in Osek by Duchnov, in the District of Teplice in Czech Republic. Since his release in 1968 he had been making a consistent effort to revive Greek Catholic Church and up until his death he took active part in its life in the bishop's role of sanctifying function. He followed Bishop Gojdic in a heroic and dignified manner, he respected him and his direction, he was exemplary in fulfilling his duties and became a shining example for the present-day generations of young priests. Bishop Vasil Hopko proved with all his life, suffering and humiliations that he is worthy of the Bishop's post. He rightly deserved the recognition as the faithful martyr for faith, Christ and the Holy Father. ${ }^{9}$

Although in 1950 the Greek Catholic Church was outlawed in Czechoslovakia and its activities were prohibited, it lived on and many of its priests remained faithful to their Church. Despite great effort of

ies in 1928 in Prešov. He was ordained a priest by Bishop Gojdič on $3^{\text {rd }}$ February 1929. His first place of service was a parish in Prague where he served until 1936. In that year he was called to Prešov by Bishop Gojdič who appointed him a spiritual in the Priest Seminary. In 1937 he serves as Consistorial Consultor. Gojdič choses him his secretary and after receiving his doctor's degree in theology he also lectures moral theology at the College of Theology in Prešov. On $2^{\text {nd }}$ January 1947 the Holy See appoints him an Auxiliary Bishop in Prešov and on $11^{\text {th }}$ May 1947 he is consecrated a Bishop by Bishop Gojdič. On $28^{\text {th }}$ April 1950, after the "Sobor (council) of Prešov", he was arrested and sentenced to 15 years in prison. His sentence was suspended in 1964 due to his bad state of health and he was moved to the monastery in Osek in the Czech Republic. He was released in 1968. On $2^{\text {nd }}$ April 1969 Pope Paul VI. ordained him a Consecrating Bishop of the Prešov Greek Catholic Episcopacy. He died on $23^{\text {rd }}$ July 1976. His mortal remains are placed in the crypt of the cathedral in Prešov. On $14^{\text {th }}$ September 2004 , Holy Father John Paul II declared him blessed in Bratislava - Petržalka.

7 P. Borza, Muž pokorného srdca, [in:] Život za mrežami, Prešov 2007, p. 118.

8 F. Dancák, Da vsijedino budut. Aby všetcijedno boli, Prešov 2002, p. 14.

9 J. Bujňák, 56. výročie vysviacky Božieho sluhu ThDr. Vasil'a Hopka za biskupa, [in:] Slovo, Prešov 2003, ch. 35, p. 8 . 
the state authority leaders, especially the secretaries for Church affairs and members of StB (State Security), the situation among the Greek Catholic Church was not developing according to the script prepared by the state authority. The Greek Catholic priests knew that converting to the Orthodox Church would be betraying their faith, so they rejected it. After some time, when the pressure built, certain priests took a different stance. Generally we can divide the Greek Catholic priests in this incriminating period into five groups:

1. those who took part in Church's liquidation (they sat at the committee table on the so called "Sobor of Prešov"),

2. those who unequivocally refused to sign the conversion to the Orthodox Church,

3. those who were hiding from the cajolers for a while,

4. those who temporized with the cajolers,

5. those who under pressure signed the conversion to the Orthodox Church. ${ }^{10}$

When neither promises nor gifts, not even threats worked, it was decreed that those Greek Catholic priests, who would not sign the conversion to the Orthodox Church, must be isolated from their believers in so called concentration camps, also called the forced labour camps (FLC). They were situated in towns such as Podolínec, Trenčín, Hlohovec, Báč, Pezinok, Hronský Beňadik, Nováky, Belušské Slatiny, Sládečkovce, Rúbaň, Močenok, and other places. Every priest was relocated from one place to another several times so they had experience with several forced labour camps. The priests were isolated for instance by transporting from the cathedral, presbytery or Ecclesiastical office, where they were lured under pretence. The state authority considered the priests, monks and theologians as the cheapest workforce and they wanted to wring as much manual labour out of them as they possibly could. It is interesting to follow the various kinds of labour our theologians and priests performed in their exile. Many of them had to attend a course or training to obtain a certificate of apprenticeship to be able to perform these jobs. The Prešov Archbishop

10 J. Babjak SJ, Zostalí verní. Osudy gréckokatolíckych kňazov. II. zväzok (5. - 8. diel), Prešov 2011, p. 495. 
and Metropolitan Mons. Ján Babjak SJ, who described the fate of these priests very faithfully and in great detail in his extensive two-tomed publication They remained faithful, states in his research that he counted one hundred and nineteen different jobs in which the priests by their honest work celebrated God. He mentions the most common: worker, storekeeper, book-keeper, miner, stoker, guard. Some of them however were even more curious: concrete worker, dredger, woodcutter, wood worker, carpenter, cow shepherd, pig feeder, cattle feeder, bricklayer, tractor driver, rail-shifter, insurance agent, lathe operator, driver, crane attendant, fish smoking and fish souring worker and so on.

All this process of expatriation of Greek Catholic priests was called the "Action 100" by the state authorities, based on the planned number of families of priests that had to unwillingly abandon their parishes and believers. When we assess this action, it's necessary to emphasize that the families of the Greek Catholic priests had to move literally from one day to the next, in a very short time and nobody discussed anything with them. The trials that the Greek Catholic priests had to suffer together with their numerous families exceeded in cruelty and malice the hardships that the priests of Latin Rite were exposed to. ${ }^{11}$

Many priests were being ceaselessly persuaded to convert to the Orthodox Church and were offered numerous benefits in the form of money, cars and so on. In this regard, the overwhelming majority of these priests resisted these alluring offers and chose the exile rather than betraying their faith. One of them was also Father Eliáš Baláž (19172008). It wasn't easy for him during the actions of "Council of Prešov". They were often approaching him to persuade him. They even offered him half a million crowns if he signs the conversion to the Orthodox Church. Mr. Bernik from District National Committee and the Church Secretary Drga were reasoning with him and trying to persuade him that if he signed he would do a good service to their new direction. Ivan Rohal'-Il'kiv, his school mate from the Grammar School, offered him a profitable job position in Bratislava with monthly salary of 20000 Kčs. It was

11 V. Vaško, Dom na skale 2. Cirkev bojující 1950 - květen 1960, Praha 2007, p. 216. 
a job of a bank director. Father Eliáš refused. He bore in mind that: "We must obey God rather than people" (Sk 5, 29). ${ }^{12}$

In the difficult moments of decision-making, the priest'sintimates, especially their parents and wives, were a great support to them. They gave them the strength to remain faithful. An example of such help is mentioned in the memoirs of Father Teodor Rojkovič (1877-1963). He was sentenced himself because he vehemently resisted the numerous offers to convert to the Orthodox Church and even to become an Orthodox Bishop, for which he was sentenced to three years of jail. Although he had been a widower since 1923 when his wife died, in his memoirs he gives beautiful testimony to the help of the wives of the Greek Catholic priests who help them endure in their faith and devotion to their Church. In one of these testimonies he writes, among others, the following words: "There were cases when some of our married priests were transported in chains to far away concentration camps. For instance, in October 1950, they brought Anton Adamkovič, Ján Fazekaš, Dr. Mikuláš Rojkovič, and Teodor Bujňák in chains from Hlohovec on the bus from Prešov. All these clerics, married, knew their holy duty that for them personally it is necessary and inevitable to abide by their Greek Catholic Faith which they took for their own when they took their holy vows. But there were also their beloved wives and children. What will become of them? How to leave them alone, helpless and penniless in poverty, exposed to persecution and exploitation of numerous authorities, secret agents, narks and opportunists? Would it really be so strange if, worried about his family, many a priest almost became willing in his heart and soul to sign his conversion to the Orthodox Church? When with this signature he would secure a future for himself and his family, an existence, good salary, content life, welfare, education, prosperity, his children's prospects... Yet the prevalent majority stayed true to their Greek Catholic faith for which they zealously suffered. And here I must point out emphatically that many of them could thank till their death for their endurance and devotion - except for the holy gratitude to God - to their devout wives, since it was their wives who encour-

12 J. Babjak SJ, Zostalí verní. Osudy gréckokatolíckych kňazov. II. zväzok (5. - 8. diel), p. 249250. 
aged them with determined words to stay true to their Greek Catholic faith for their sake and to hold on to it until their death, regardless of imprisonment, persecution and suffering of the women and their families. God will help us, said the wives, to survive without you, He will not abandon us!"13

How did the Greek Catholic believers actually react to the liquidation of their Church and its incorporation into the Orthodox Church? The answer to this question is in fact a bit more difficult, since we do not have the exact statistical data at our disposal. The first reactions of the population to the decree of so called "Council of Prešov" cannot be fitted into the narrow antitheses of positive and negative. The reactions were varied yet expressing anything but spontaneous agreement. The abolition of the Union was welcomed by only a tiny fraction of believers. ${ }^{14}$ In the following periods, we could generally divide the believers according to their reactions in the situation they found themselves in, regarding the attempt to liquidate and outlaw their Church, into two groups.

One section of believers, perhaps not immediately but gradually, started to attend the Orthodox Service. The reasons were varied. It was sometimes the presence of their priest who stayed among them now as an Orthodox priest, but many considered him "their own". Another reason was the fact, that the liturgy was celebrated in more or less similar manner, since the Greek Catholic believers practice the East Byzantine Rite, same as the Orthodox believers. The second group of Greek Catholics was formed by two subgroups. After the official abolition of their Church, one part of believers rejected the Orthodox Church and sought the way to the Roman Catholic Church. It was a path of thorns, since the official conversion to the Catholic Church through the Registrar's Office in the first part of 1950s was virtually impossible. ${ }^{15}$ Another group contained those Greek Catholic believers who rejected the Orthodox Church but did not incline

13 P. Borza, Likvidácia Gréckokatolíckej cirkvi v spomienkach Teodora Rojkoviča, [in:] Cirkev v okovách totalitného režimu. Likvidácia Gréckokatolíckej cirkvi v Československu v roku 1950, eds. J. Coranič, P. Šturák, J. Koprivňáková, Prešov 2010, p. 140-141.

14 J. Pešek, M. Barnovský, Štátna moc a Cirkvi na Slovensku 1948-1953, Bratislava 1997, p. 249250.

15 J. Pešek, M. Barnovský, Pod kuratelou moci. Cirkvina Slovensku v rokoch 1953-1970, Bratislava 1999, p. 27. 
to the Roman Catholic Church either. Although they had no temples and no priests, they remained persistent to the doctrine of the Greek Catholic faith. They celebrated services and other sacraments themselves by the cross, at the cemetery or in somebody's house. For these groups, sacraments and liturgies were gradually celebrated by the returning priests coming back to the region of Eastern Slovakia at the time of certain respite, which was previously strictly forbidden. ${ }^{16}$ In some parishes, the Greek Catholic believers proved their devotion to their church, when for many years, in some cases during the whole time of 18-years long oppression, they did not allow Orthodox Services in their churches? (Abranovce, Olšavica, Sulín and others). ${ }^{17}$ The fact that the situation was closely monitored on the part of the state and political authorities is attested by the Report on the consolidation process in the Orthodox Church in the Eastern Slovakia and on the activities of the unauthorized sects in Slovakia from $5^{\text {th }}$ May 1955: "The believers belonging to the Orthodox Church can be divided into three groups: one is obedient to ? the Orthodox priest, attends the Orthodox church (about $50-60 \%$ in total); the second is radically against, only goes to the Roman Catholic church and demands the Holy Sacraments (christenings, funerals) from the Roman Catholic priests; and the third group does not acknowledge either Orthodox or Roman Catholic priests, but celebrates the sacraments at the cemeteries and at the cross behind the village in summer and in the private houses in winter. The last group is the most undesirable because it provides a hotbed of unauthorized sects and the activities of the enemy-of-state elements."

\section{The Greek Catholic Church in the context of the situation of society-wide changes in 1968}

The political tension in Czechoslovakia in 1968 was manifested in several regards. It was a result of accumulated injustices. The main dis-

16 See: J. Pešek, M. Barnovský, Pod kuratelou moci. Cirkvi na Slovensku v rokoch 1953-1970, op.cit., p. 27.

17 G. Székely, A. Mesároš, Gréckokatolíci na Slovensku, Košice 1997, p. 26. 
cord was taking place inside the Communist Party of Czechoslovakia (KSČ) in 1968 and the Communist Party of Slovakia (KSS) - the leading power in the state. The discontent with the politics of KSČ culminated at the congress of the Central Committee during the $3^{\text {rd }}$ to $5^{\text {th }}$ January 1968. Antonín Novotný resigned from his leading capacity in the Party apparatus and Alexander Dubček ${ }^{18}$ was appointed the first secretary of the Central Committee of KSČ. It marked a turning point in the political, social, but also in the religious life. Alexander Dubček begins to advocate the so called "socialism with a human face."

During the preceding period it was the Church that suffered most. Therefore it was natural that it demanded their rights. On the abovementioned plenum in January, the censure was cancelled and from then on, although initially a bit shyly and not radically enough, the pastors and believers formulated their demands. The bishops from all over the Republic gathered in Prague as early as on $8^{\text {th }}$ February to discuss the issue of land reform of Church's properties. Thereafter the priests, too, convened in Trnava on $14^{\text {th }}$ March 1968. They condemned the Peace Movement of the Catholic Clergy, demanded the reinstatement of the Catholic press, staff changes on the Faculty of Theology, the rehabilitation of monastic life and the freedom to teach religion in schools. ${ }^{19}$ One of the most significant ecclesiastical events of that exceptional year was the establishment of the Action for (Vatican) Council Renewal (AVCR) on 14 ${ }^{\text {th }}$ May 1968. The Bishop of Trnava ThDr. Ambróz Lazík ${ }^{20}$ became its chairman. The AVCR issued a statement with the explicit demands for the Catholic renewal: government negotiation with the Holy See, government's agreement with the bishops, free contact of the bishops with the Pope, return of the bishops' cathedra to the deposed bishops, bishops' conferences free of interference, free practice of Episcopal duties in their Office, in the seminaries, in the construction of churches, presbyteries and facility buildings. In leading the priests without the interference of the District Committees, the rehabilitation of monastic life, the renewal of the rights for the Greek

18 V. Judák, E. Čekovská, Prehl'adné cirkevné dejiny, Bratislava 1996, p. 246.

19 Š. Šmálik, Vel'ký štyridsatročný pôst Cirkvi na Slovensku, Bratislava 1996, p. 43.

20 A. Hlinka, Sila slabých a slabost' silných, Bratislava 1990, p. 73. 
Catholics, the removal of the obstacles in the religious life of laymen, the redress of injustices from religious prosecution, religious education of the young both in and outside of schools, the Church's access to press, broadcasting and television, pastoral work in the hospitals and prisons. ${ }^{21}$

The Renewal Process of Church and the whole society in 1968 was, however, violently interrupted, when on $21^{\text {st }}$ august 1968 the armies of Warsaw Pact occupied Czechoslovakia and even the attempt of Alexander Dubček to constitute the "socialism with a human face" 22 was thwarted. This was reflected in the pastoral letter of the Slovak Apostolic Administrator from $18^{\text {th }}$ September 1968: "There are days and hours in the life of man and in the life of nations that are such heavy burdens that we cannot remain indifferent to them... It is our duty to endure these days in the spirit of Gospel's repentance which means the change of the way of thinking, the inner reform of the heart." ${ }^{23}$ The change in the life of society in the negative meaning of the word was brought by the directive of "normalization" of the public life enacted in the days of $19^{\text {th }}$ to $30^{\text {th }}$ May on the congress of the Central committee of KSČ and it brought about the renewal of Marx-Lenin unity of KSČ, the renewal of the leading position of the party.

How did these events reflect into the life of the Greek Catholic Church in the former Czechoslovakia? All the social changes found their strong resonance in the Greek Catholics, too. One of the first voices of the forcibly silenced Church was a private request of the Bishop Vasil Hopko from the $19^{\text {th }}$ March 1968, at that time still living in the internment of the monastery in Osek, to the National Assembly of ČSSR (Czechoslovak Socialist Republic) in Prague, in which he put forward his plea to invalidate the outlaw status of the Greek Catholics. In the letter, Bishop Hopko asked among others: "I consider it my civic duty, as one of them (i.e. the simple citizens who do not know that they could defend their rights in a non-violent manner), as their Greek Catholic Bishop, after many years of imprisonment, I demand for the abovementioned government decree

\footnotetext{
${ }_{21}$ Š. Šmálik, Vel'ký štyridsatročný pôst Cirkvi na Slovensku, Bratislava 1996, p. 44.

22 V. Judák, E. Čekovská, Prehl'adné cirkevné dejiny, Bratislava 1996, p. 246.

23 Š. Šmálik, Vel'ký štyridsatročný pôst Cirkvi na Slovensku, op. cit., p. 47.
} 
signed by the Minister Frierlinger to be revoked as soon as possible, so that the Greek Catholic Church, together with his Bishop Pavol Gojdič, deceased in prison, was rehabilitated and have its lawful rights reinstated, the same as the other Churches." ${ }^{24}$

The request of the Bishop ThDr. Vasil' Hopko was supported not only by the Catholic Episcopacy in Czechoslovakia, but also by the believers. Subsequently, the Greek Catholic Church Action Committee was established in Košice, mainly from the initiative of Dr. Ján Murín. The purpose of this Committee was to advocate the interests of Church and to publicly act as the Eparchy on behalf of all priests. The Committee summoned all the priests living in the Eparchy of Prešov for the assembly on $10^{\text {th }}$ April 1968. The great council took place in the assembly hall of the Roman Catholic Episcopacy in Košice. After eighteen years, the assembly in Košice gathered almost all the priests. Out of 172 living priests, 133 attended the assembly. ${ }^{25}$ The most beautiful moment of the council took place when the only living Bishop of the Eparchy of Prešov Mons. ThDr. Vasil' Hopko entered the assembly hall. The priests welcomed him with the riveting liturgical song "Vošel jesi archijereju vo cerkov Božiju..." Father Bishop then performed the ceremonial opening of the council. Although his health was ruined, the whole assembly could hear the indescribable joy he felt in his voice. The result of the assembly was the resolution demanding to declare the so called "Sobor (council) of Prešov" from $28^{\text {th }}$ April 1950 null and void and to rehabilitate the Church, bishops, priests and believers. The Action Committee counting seventeen members was also permanently established under the leadership of Father Bishop ThDr. Vasil' Hopko. When the assembly finished, the priests present went home to their respective parishes and awaited the further development of the situation. The delegation of the Action Committee led by Father Bishop ThDr. Vasil Hopko negotiated with the Commissioner of Culture and Information in Bratislava on $22^{\text {nd }}$ April 1968. The result of the negotiation was an agreement, that Bishop Hopko would be rehabilitated and would get the state permission for practicing the pastoral work.

24 F.Vnuk, Popustené putá. Martin, Matica Slovenská 2001, p. 186.

25 M. Fritz, Trpké roky. Spomienky gréckokatolíckeho kňaza, Košice 1993, p. 78. 
On request of the Commissioner he pledged himself to issue a statement to the Greek Catholic and Orthodox believers in which he would encourage them to conciliatoriness. In May 1968 Bishop Hopko issued a letter in which he called upon the believers to await the renewal of their Church patiently and without violence. ${ }^{26}$ The efforts for renewal of the Greek Catholic Church in Czechoslovakia met with great displeasure in the ranks of the Orthodox Church. ${ }^{27}$ As early as April 1968 the eight-member delegation of the Orthodox Church visited the Commissioner Brenčič and the Chairman of Regional Committee of the Eastern Slovak Region Ing. Jozef Kubošovský. On this meeting they were making allegations pointing out the "subversive activities of the Greek Catholic Church" and the fact that "the Orthodox Church is being accused by the Greek Catholics to have usurped all the Greek Catholic properties" and similar. They repeated that the Orthodox Church was not against the permission for the Greek Catholic Church to function, but the negotiations should not be based on the situation from before the $28^{\text {th }}$ April 1950 , but rather on the current state of affairs." ${ }^{28}$ In spite of all wrongdoings on the part of Orthodox representatives, the Greek Catholic Church practice and functioning was permitted by the government resolution from $13^{\text {th }}$ June $1968 .^{29}$ After eighteen years the Greek Catholic priests could once more fulfill their mission like the priests of other Churches. In July 1968, the Commissioner for Culture and Information granted his approval for establishment of the Greek Catholic Episcopacy which took place on $17^{\text {th }}$ July 1968. Father Andrej Zima was appointed the Director of the Episcopacy residing in Košice, ThDr. Ján Murín was appointed the Secretary, ThDr. Štefan Ujhelyi became their third colleague; the administration of the Episcopacy was in their hands, since Father Bishop

26 J. Voroňák, ThDr. Vasil' Hopko - pomocný prešovský biskup, [in:] Blahoslavený biskup Vasil' Hopko. (1904-1976). Zborník príspevkov z vedeckej konferencie konanej na GTF PU v Prešove z príležitosti 100. výročia narodenia biskupa Vasilla Hopka, Prešov 2004, p. 46.

27 See: P. Borza, Blahoslavený Vasil' Hopko prešovský pomocný biskup (1904-1976), Prešov 2003, p. 71.

28 Sna, ÚV KSS - preds, kart. 1205.

29 Vládne nariadenie z 13.júna 1968 o hospodárskom zabezpečenígréckokatolíckej cirkvi štátom, [in:] Kalendár gréckokatolikov 1969, Trnava 1969, p. 49-50. 
ThDr. Vasil' Hopko had not yet been rehabilitated. In the same month, the Main Cathedral of Saint John Baptist in Prešov was returned and reestablished, having been in the possession of the Orthodox Church up until then. The Episcopal Residence, however, remained in the possession of the Orthodox Church. ${ }^{30}$

Another important event took place in 1968. The mortal remains of Bishop Pavol Peter Gojdič OSMB were exhumed and then transferred from the cemetery in Leopoldov to Prešov. The turbulent situation then was even more aggravated on $21^{\text {st }}$ August, when Warsaw Pact Armies invaded Czechoslovakia. This fact gradually halted the reform process in the whole republic. Although the Greek Catholic Church was legalized and in theory granted equal rights to other Churches recognized by the state, in reality the conditions to freely develop its function were far from ideal. Despite these restrictions and obstacles the Greek Catholic Church made every effort to build and develop the spiritual life of its believers. Alongside the permission to function, it was necessary to re-establish administrative bodies of the Eparchy lead by a Bishop. On $2^{\text {nd }}$ April 1969, after the socio-political changes, Mons. Ján Hirka was appointed an Interim Apostolic Administrator with the rights of a Residential Bishop and ThDr. Vasil' Hopko was appointed a Consecrating Bishop for the Prešov Eparchy. After many years of the Greek Catholic Church being outlawed in Czechoslovakia, shortage of priests who could take on pastoral work became an imminent issue. On the grounds of that, on $21^{\text {st }}$ December 1968, Apostolic Administrator Ján Hirka requested the Greek Catholic Theological Faculty and Priest Seminary in Prešov to be established. He directed his letter to the Secretariat for Religious Affairs in Bratislava and the main reason he gave was: an acute shortage of priests. The request contained a comparison with the year 1948 when there were 335 priests in 245 parishes. In the year 1968 there were only 163 priests in pastoral work. Apostolic Administrator in Prešov addressed to the Ministry of Culture - the Secretariat for Religious Affairs several requests regarding re-establishment of the Theological University. "Request to re-establish the Greek Catholic Priest Seminary and the Theological Faculty in Prešov,

30 P. Borza, Muž pokorného srdca, op. cit., p. 120. 
dated $26^{\text {th }}$ January 1971 , No.178/71" states that there were requests addressed to the Secretariat dated $15^{\text {th }}$ August 1968, $21^{\text {st }}$ December 1968, $5^{\text {th }}$ July $1969,18^{\text {th }}$ December 1969 and $5^{\text {th }}$ February $1970 .^{31}$

No matter how justified, all these requests, however, remained unanswered and for the long 23 years Greek Catholic theologians studied in limited numbers (on average 2-4 in a year) at the Roman Catholic Theological Faculty of Cyril and Methodius in Bratislava and at the Roman Catholic Theological Faculty of Cyril and Methodius in Litoměrice. During the era of "normalization” as well as in the following period up until 1989, the Greek Catholic Church was barely tolerated and suffering. The state supervision over Churches strengthened and assumed great proportions. After the death of the Consecrating Bishop ThDr.Vasil' Hopko in 1976, there was nobody to ordain the servants of the altar. Therefore, bishops from the former Yugoslavia, namely Dr. Joachim Segedi and then Slavomír Miklovš, had to come to Prešov to ordain our priests.

A separate issue related to the above mentioned gradual liquidation of the Greek Catholic Church during the totalitarian era were the sacred buildings- cathedrals and presbyteries. Despite the fact that the cathedrals in reality belonged to the Greek Catholic Church, their common use was forced upon them by power authorities. Wherever this was practised, it did not contribute to the peaceful life of the believers. On the contrary, it only caused frictions and misunderstandings.

The function of the Greek Catholic Church was thus barely tolerated. This concerned religious education at schools as well as celebration of local "odpust" in parishes. Pilgrimages known in the Eparchy, namely Klokočov, Čirč and especially L'utina, posed the main problem with the power authorities. During the totalitarian era in the 70's and 80's Lutina became a place for manifestation of faith for all Greek Catholics. In 1988 Holy Father John Paul II designated it a basilica minor.

31 AGBP, without sign., Žiadost’ o obnovenie činnosti gréckokatolíckeho kňazského seminára a bohosloveckej fakulty $v$ Prešove, 26.1.1971, p. 1. 


\section{Summary}

\section{The situation of the Greek Catholic Church in Slovakia in the second half of $20^{\text {th }}$ century}

The past $20^{\text {th }}$ century has many attributes and names. It can be said that it was century of martyrs, but it is also century of the victories of God. In connection with this, ecumenical memory of $20^{\text {th }}$ century martyrs took place on $7^{\text {th }}$ May 2000 in Colosseum in Roma, where Holy Father also said: „At the places, where it seemed that hatred will diminish the whole life and it will be impossible to run from it, witnesses of God showed that love is stronger than death. In terrible systems of tyranny which outraged a man at the places of pain, in hunger and various torments, they showed that they belong to Christ, crucified and resurrected Lord... Let the memory of our brothers and sisters-martyrs be still alive in following century and millennium. Let it be passed from generation to generation to make deep Christian recovery flow from it. Let guard the memory of martyrs as the jewel of incredible price for the Christians of the new millennium." These words also fully refer to the Greek Catholic Churuch in Czechoslovakia, which in its history and in the mentioned century underwent hard tests, but it has persevered in faith and loyalty to God. The Greek Catholic Church suffered from pressure of the totalitarian regime the most, it even made its martyrs. While the other Churches were disturbed and weaken, the Greek Catholic Church was directly administratively liquidated.

Keywords: history, Church, Greek Catholic Church, bishop Gojdič, martyr

\section{Sytuacja Kościoła greckokatolickiego na Słowacji w drugiej połowie XX wieku}

Miniony XX wiek ma wiele charakterystycznych cech i znaków czasu. Można powiedzieć, że XX wiek był czasem męczenników, ale i stuleciem Bożych zwycięstw. Słowa te w pełni można odnieść do słowackiego Kościoła creckokatolickiego, który przeszedł w całej swojej historii, ale przede wszystkim w drugiej połowie XX wieku, wiele prób, ale wytrwał w wierze i wierności Bogu. Kościół greckokatolicki doświadczył prześladowania ze strony totalitarnej władzy, do męczeńskich śmierci włącznie. Podczas gdy inne Kościoły były niszczone i osłabiane, greckokatolicką administrację całkowicie likwidowano.Działo się to w ramach nowego podziału świata po II wojnie światowej, kiedy Czechosłowacja, otrzymując władzę komunistyczną, równocześnie dostała się pod wpływ ideologiczny Moskwy. Pojawienie się władzy komunistycznej spowodowało radykalne ingerowanie we wszystkie dziedziny życia. Szczególnie przejawiało się to w atakach i walce z Kościołem, który zyskał z czasem w Czechosłowacji przydomek „wojujący”. Przeprowadzoną w 1950 roku operację próby zniszczenia Kościoła greckokatolickiego władza państwowa nazwała „Soborem preszowskim”. Mimo tych wszystkich działań 


\section{Peter Šturák}

zniszczenie Kościoła nie powiodło się, ponieważ Kościół jako instytucja bosko-ludzka ma boski fundament, zatem jest niezniszczalny. Kościół nadal istniał w postaci jego wiernych cierpiących w więzieniu - byli nimi zarówno biskupi: bp Paul Peter Gojdič OSBM i ks. Vasil Hopko, jak również wielu kapłanów i wiernych świeckich, zmuszonych do wygnania poza czeskie granice. Pewna odwilż nastąpiła w 1968 roku, co odbyło się w kontekście szerszych przemian społecznych, ale początek procesu normalizacji to dopiero rok 1989 - wcześniej wznowiona działalność byłą jedynie tolerowana.

Słowa kluczowe: historia, Kościół, Kościół greckokatolicki, bp Gojdic, męczennik

\section{Bibliography}

Babjak J. SJ, Zostalíverní. Osudy gréckokatolíckych kňazov. II. zväzok (5. - 8. diel), Prešov 2011.

Borza P., Blahoslavený Vasil' Hopko prešovský pomocný biskup (1904-1976) ,Prešov, 2003. Borza P., Muž pokorného srdca, [in:] Život za mrežami, Prešov 2007, p. 111-122.

Borza P., Likvidácia Gréckokatolíckej cirkvi v spomienkach Teodora Rojkoviča, [in:] Cirkev $v$ okovách totalitného režimu. Likvidácia Gréckokatolíckej cirkvi v Československu v roku 1950, eds. J. Coranič, P. Šturák, J. Koprivňáková, Prešov 2010, s. 140-141.

Bujňák J., 56. výročie vysviacky Božieho sluhu ThDr. Vasil'a Hopka za biskupa, [in:] Slovo, Prešov 2003, ch. 35, p. 8.

Coranič J., TZV. „Prešovský sobor” - vyvrcholenie úsilia totalitnej moci o likvidáciu Gréckokatolíckej cirkvi v Československu, [in:] eds. J. Coranič, P. Šturák, J. Koprivňáková, Prešov 2010, p. 63-88.

Dancák F., Da vsi jedino budut. Aby všetci jedno boli, Prešov 2002.

Fritz M., Trpké roky. Spomienky gréckokatolíckeho kňaza, Košice, 1993.

Hlinka A., Sila slabých a slabost' silných, Bratislava 1990.

Hromník M., Blahoslavený Pavel Peter Gojdič, OSMB, Prešov 2007.

Judák V., Čekovská E., Prehl'adné cirkevné dejiny, Bratislava 1996.

Pešek J., Barnovský M., Štátna moc a Cirkvi na Slovensku 1948-1953, Bratislava 1997.

Pešek J., Barnovský, M., Pod kuratelou moci. Cirkvi na Slovensku v rokoch 1953-1970, Bratislava 1999.

Székely G., Mesaroš A., Gréckokatolíci na Slovensku, Košice 1997.

Šmálik Š., Vel'ký štyridsatročný pôst Cirkvi na Slovensku, Bratislava 1996.

Vaško V., Dom na skale 2. Cirkev bojující 1950 - květen 1960, Praha 2007.

Voroňák J., ThDr. Vasil' Hopko - pomocný prešovský biskup, [in:] Blahoslavený biskup Vasil' Hopko (1904-1976). Zborník príspevkov z vedeckej konferencie konanej na GTF PU v Prešove z príležitosti 100. výročia narodenia biskupa Vasil'a Hopka, Prešov 2004, p. 40-49.

Vnuk F., Popustené putá, Martin 2001. 